\title{
Presenting without power(point)
}

7 he invitation to speak was printed on satisfyingly heavy paper. "Please accept the committee's invitation to speak on 'Pneumocystis infection in AIDS' at the 5th Pan-

Eurasian Nosocomial Infection Society. The meeting will be held 14th-16th November 2003 in X." I'd not heard of " $\mathrm{X}$ " for many years. In fact not since I studied ' $\mathrm{O}$ ' level geography, when I remember it was (and still is) the capital city of Y. My ego inflated. I asked my secretary to respond with indecent haste in order to confirm my participation. Her blushes caused me to re-read the invitation and made me aware of the conference organising committee's acronym. A few days later a letter arrived, confirming arrangements for travel, hotel, and conference registration. Buried in the small print at the bottom of the letter was the statement that "PowerPoint facilities will not be available." A month before the conference I made slides for my talk and I was reassured when flight tickets and details of hotel accommodation arrived by courier.

With some excitement, and considerable "jetlag" I arrived in X. Heat, humidity, and the omnipresent pale purple flowers of the jacaranda tree greeted me. After a sleepless night, despite melatonin, in a room with broken air conditioning, I finally relaxed while eating breakfast by the hotel poolside. The idyll was broken by the arrival of the conference bus, which took several delegates and me across town to the conference centre-a stunningly beautiful building conveniently situated next to the beach.

As my talk was not scheduled until the session after the mid-afternoon break I spent the morning catching up with friends and planning future collaborations, while listening to the sound of waves on the shore and watching the more adventurous surfers attempt to defy gravity. During the lunch break I met up with the AV technician, loaded my slides, and checked that they worked on the projector, which was perched on a very tall stand in the middle of the lecture theatre. The lecture theatre itself was unusually long and narrow. Along one side there were several huge blinds hanging in unglazed window spaces, through which the sound of the sea echoed and the smell of jasmine wafted in on the hot and humid breeze.

The chairman began the session on time, with an introduction that went on for ages. Unannounced, he began to present his own group's data-to increasing incredulity from both audience and speakers. Fifteen minutes after my scheduled start time I was finally "on." As I began to speak I noticed that my first slide was moving in slow motion in an arc down and to the right across the screen-and then it disappeared. A millisecond later there was a loud crash, followed by a screech, as the large cat that had leapt in from a window landed on the projector, knocking it flying.

Recovering the projector and my composure the AV technician and I resumed the talk. The cat made its own exit arrangements. I was finally in full flow when there was a loud bang outside the room; at the same time the power failed and the room was plunged into darkness. I realised that I was the only person in the room who was standing. Uncertain as to the cause-a gas leak, a bomb?-I went with the flow and hit the deck. Lying on the floor next to me the chairman informed me that he had instructed the AV technician to carefully crawl outside to establish the cause.

Several tense minutes later, the power was restored, just as the AV technician returned. He was grinning from ear to ear, having identified the cause of our power failure. Two cleaners were working outside the lecture theatre using a rotary floor polisher. The lack of a plug on the power cable had not deterred them and they'd simply stuck bare wires into the wall socket. All was well until the cleaners reached the extreme extent of the polisher's cable and the bare wires had touched-shorting not just the socket but also the entire ring main.

I resumed my talk and within seconds noticed the chairman was rolling his eyes wildly, gesticulating at the clock on the wall above the door, and making an unusual cutting movement using the side of his hand against his throat. Like all considerate speakers I behaved impeccably. Shifting my position I turned away from the chairman and, unruffled, I continued to deliver my pearls. Far more effective than the chairman's attempts to halt my flow was the sudden arrival of a huge samovar, perched precariously on top of a squeaky trolley. This was manoeuvred into the room by two giggling domestics who, oblivious to the activity in the lecture theatre, began to offer tea to the audience, at the same time discussing noisily the (lack of) attributes of their respective husbands. Finally defeated I put up my last slide-to rather more applause than I get after most of my talks.

It's all rather quiet in 2004. I have no invitations in my diary to speak. I wonder if this might have something to do with the fact that I have responded to all the recent invitations to speak with a demand for a blackboard and chalk?

R Miller
Balham, London, UK; rmiller@gum.ucl.ac.uk 